\title{
Business processes reengineering at the enterprise in terms of its ecological responsibility
}

\author{
Ismail Shakhgiraev ${ }^{1, *}$, Tatyana Kondratyeva ${ }^{2}$, Askerbek Uazikov ${ }^{2}$ and Alexey Kuzmin ${ }^{3}$ \\ ${ }^{1}$ Chechen state university, Sheripov St., 32, 364907, Grozny, Russia \\ ${ }^{2}$ Moscow State University of Civil Engineering, 26, Yaroslavskoye Shosse, 129337, Moscow, Russia \\ ${ }^{3}$ Saint Petersburg State University, Universitetskaya Embankment, 7-9, 199034, St. Petersburg, \\ Russia
}

\begin{abstract}
The principles and technique of business processes reengineering at the enterprise are generalized in this article. The authors name the issues which can be solved by the means of reengineering at the modern enterprise. Having analyzed the experience of the enterprises, the authors reveal those factors that promote success of reengineering. It has been considered for years that the main scope of the new equipment and technology is the production and, first of all, processing. But according to the authors, in modern conditions, the technician and technology have to be used not only for production and commercial tasks but also for the increase in environmental friendliness of the enterprise activity, its responsibility for the influence on the environment state.
\end{abstract}

\section{Introduction}

From the middle of the 1970th the new ideas, connected with the special approach to realization of the new equipment and scientific and technical progress in production and consumption of products began to get into world business practice. First of all, that was engineering or everything connected with the engineering concept. Engineering represents the engineering-and-consulting services isolated to the independent sphere of commercial activity. Such services are divided into two groups: those connected with production preparation and those for providing the normal production processes and products sales.

Works of many scientists can be used as the theoretical basis for the reengineering investigation, including: I. Ansoff, P. Druker, B.C. Efremov, A.N. Petrov, M. Porter, A. Strickland, A. Thompson, and others. Experts in the field of reengineering include $\mathrm{M}$. Hammer, J. Ciampi, T. Davenport, J. Short, E.G. Oykhman, E.V. Popov, E.A. Utkin and others; experts in the field of development of the concept of business processes and their modeling are K. Simon, P. Strassman, J. Harrington, D. Morris, J. Brandon, V.F. Kravchenko, P.V. Zabelin, V.A. Ivlev, M.S. Kamennov and others [1-12].

The American scientist M. Hamler was the first to introduce the term "reengineering" for the scientific use, he gave the following definition: reengineering is the fundamental

\footnotetext{
* Corresponding author: angela-1309.m@yandex.ru
} 
reconsideration and radical redesign of business processes for achievement of sharp, spasmodic improvements of modern indicators of a company activity, such as cost, quality, service and rates. This definition contains four key concepts: "fundamental", "radical", "sharp" ("spasmodic") and "process". Though the concept "process" ("business process") is the most important in this context, it is difficult to explain it to managers as most of them got used to deal with tasks, works, structures, people, but not with processes. Thus, the investigation on the nature of the business processes reengineering at the enterprise, its principles, stages, factors of efficiency remain relevant. The purpose of engineering activity as well as reengineering is the increase in the production efficiency on the basis of the achievements in the field of engineering knowledge, known in science and practice. In modern conditions, these achievements have to be directed not only to the achievement of the economic benefit, but also for the social benefit and ecological well-being.

\section{Methods}

The methods of statistical analysis and synthesis were the basis of the study.

The basic principles of business processes reengineering include:

- concentration of responsibility: several working procedures unite in one (horizontal compression of process);

- delegation of powers in combination with self-checking: performers make independent decisions (vertical compression of process);

- natural order of performance of process, for example parallel order, but not consecutive;

- $\quad$ various options of execution of processes depending on the situation;

- work performance where it can be made most effectively (up to its transfer to the client);

- reduction of volume of coordination, checks and control; the control from managers is replaced with the control from consumers of this process (whenever possible).

Within the reengineering technique special attention is paid to the formation of a team and its interaction with the staff of the organization. Process teams replace the old structure of management.

Depending on the performed works two types of process teams are used most often:

- the team, which unites in common working people of the different specialties, performing the routine and repeating work for a long time;

- the team, which unites people to solve a non-standard and (as a rule) difficult task. Teams of this kind are formed for the period of the task solution and upon the completion of the project they are disbanded. The same worker can be at the same time the member of several teams, distributing his or her time among several projects.

The definition of participants of reengineering activity and the functions, which are carried out by them, are the basis of the process efficiency (Table 1).

It is possible to list the main methods of reengineering, which intersect with its principles:

1. Elimination of excessive or long flows (that is about check, coordination, tracking, i.e. the actions, which do not have their own value for clients).

2. Elimination of gaps and "blind places" in the business processes (when process is not regulated anyhow and every time it is carried out at the discretion of the personnel).

3. Involvement as few resources as possible in business process (reduction of resources by combination of the tasks which are carried out per one worker, etc.).

4. Performance of business process by clients or suppliers (outputting of the key business processes out of the company). 
5. Creation of a set of versions of difficult processes (exceptions and special situations cease to take place, as everything is provided in advance).

6. Creation the built-in mechanisms of control (determination when control is expedient, and to create some business processes with the built-in mechanisms of control, and others without).

7. Reduction of the cycle duration (by the means of the increase in the share of useful time due to association of all the stages in the same place at the same time, because of the cut transport costs; reduction of periods between performance of different stages of process, careful planning; reduction of idle times, transportation, etc.).

8. Integration of several works in one (integration of earlier separated works in one).

9. Simplification of works (by the means of to increase in complexity of tasks of each worker).

Table 1. Participants of reengineering activity and their function.

\begin{tabular}{|l|l|}
\hline \multicolumn{1}{|c|}{ Participants } & \multicolumn{1}{c|}{ Functions } \\
\hline $\begin{array}{l}\text { 1. Head of the project is one of the top } \\
\text { managers of the firm }\end{array}$ & $\begin{array}{l}\text { Leadership in reengineering activity, } \\
\text { responsibility for ideological justification of the } \\
\text { project, creation of the general spirit of innovation } \\
\text { and responsibility }\end{array}$ \\
\hline $\begin{array}{l}\text { 2. Managing committee include the } \\
\text { members of the top management, the } \\
\text { leader of the project, processes managers }\end{array}$ & $\begin{array}{l}\text { Observation, coordination of objectives and } \\
\text { strategy, of working teams interests, resolution of } \\
\text { conflicts }\end{array}$ \\
\hline 3. Operational managers & $\begin{array}{l}\text { Development of the technique and instruments of } \\
\text { reengineering; training, coordination, help in the } \\
\text { formation of teams }\end{array}$ \\
\hline $\begin{array}{l}\text { 4. Processes managers } \\
\text { Development of the technique and instruments of } \\
\text { reengineering; training, coordination, help in } \\
\text { formation of teams }\end{array}$ \\
\hline $\begin{array}{l}\text { 5. Working teams include the employees } \\
\text { of the firm as well as external } \\
\text { consultants and developers }\end{array}$ & Direct work on reengineering \\
\hline
\end{tabular}

Concrete tools which are used for the implementation of reengineering are presented in Figure 1.

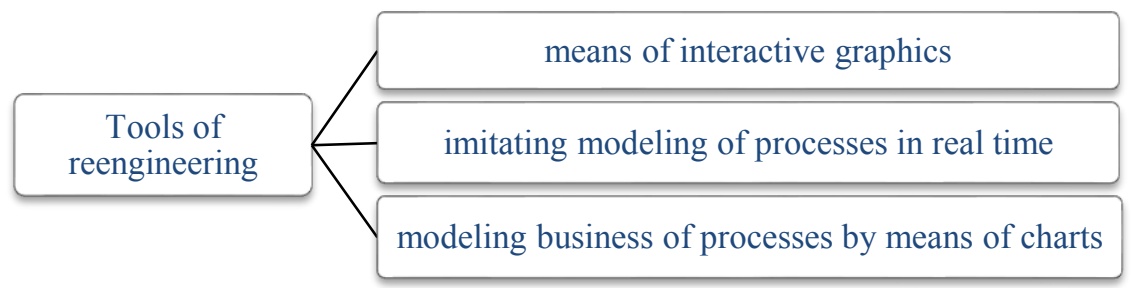

Fig. 1. Instruments of reengineering.

Stages of the business processes reengineering technique include the following actions:

1) development of the project and emphasizing the business processes. The purposes and tasks of the project are defined, the reengineering team is formed and the approach to reengineering is chosen;

2) documenting of business processes. At this stage, the creation of graphic models of business processes is carried out on the basis of the offered technique of their documenting, compound operations of business processes are timed: 
3) comparative analysis of business processes (benchmarking). The analysis of business processes for the purpose of comparison them with the business processes of the advanced divisions of the organization or rival enterprise is carried out;

4) development of the future organization image. The purpose of this stage is to formulate a frame of reference on the new enterprise according to its purposes and opportunities. It is expedient to include subjects of the external environment in the reengineering team;

5) analysis of problems and redesign of business processes and technologies. The purposes of this stage are:

- identification of problem places in the technological and business processes:

- introduction of new business processes, technologies and the results assessment.

At the last stage it is necessary to compare results of efficiency of functioning of business processes with the criteria, which were set at the beginning of reengineering, taking into account cost of types of functional activity.

Four phases can be named within the procedure of carrying out business processes reengineering at the enterprise: Planning, Reengineering, Transformation and Introduction.

\section{Results}

In general reengineering solves the following problems:

- promotes the creation of network of communications for extraordinary conditions (as it develops horizontal managerial communications);

- creates organizational prerequisites for centralization of information flows (as it promotes obtaining information systematized on concrete processes);

- promotes division of functions of the top management and creation of network of task teams (as it allows applying technology of work of process teams to these purposes);

- motivates the creative approach, analyzes situations and collective work (as on the basis of these principles the character of work and the role of workers change during reengineering);

- allows combining the coordination of strategy from the center and the decentralized execution of decisions successfully (as it relies on the mixed processes and matrix structures of management);

- creates organizational conditions to restructuring of the enterprise (as it coordinates the changes of structure of management to activity of process teams).

The analysis of successful examples of reengineering proves that success of the process is caused by certain factors (Figure 2).

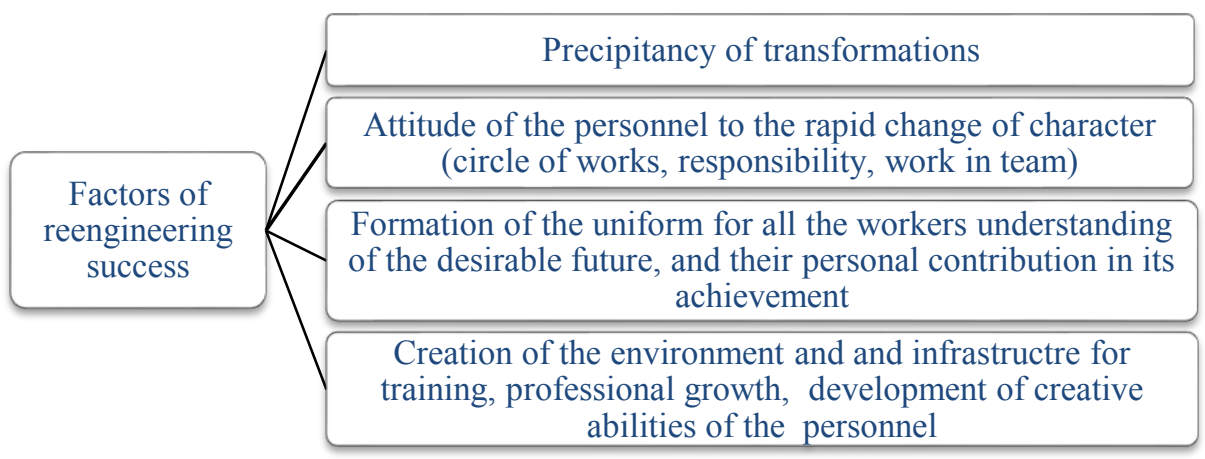

Fig. 2. Factors of reengineering success. 
In case of success reengineering increases the enterprise mobility upon the transition to anti-recessionary technologies of management. That is especially important in modern Russian conditions.

\section{Discussion}

As any method, reengineering is exposed to criticism.

In practice reengineering can lead to a gap between actual state of processes and what they "had to be". Reengineering assumes the implementation of large-scale changes, which can lead to disorganization of processes of the enterprise during its implementation. In practice reengineering is often followed by staff reduction, by appeal to external resources and restructuring of all the work. That causes extremely negative relation of all personnel. A great disadvantage of reengineering is the huge risk, as in case of failure of the reengineering project the organization can come to crash. The risk is connected with certain cardinality of transformations, instability, the need of high concentration of resources, high level of personnel resistance, rising cost of reengineering. Money and time, spent in vain, the missed opportunities and the destroyed structure of the organization can be the deplorable result of reengineering. After carrying out reengineering newly created processes should be operated with the efficiency corresponding to them, and that also causes some difficulties for managers.

\section{Conclusions}

Reengineering is necessary as it increases the enterprise mobility, its innovative potential, environmental friendliness of its activity; that is very important in modern Russian conditions. It is difficult to give any general advice how to execute reengineering at a certain enterprise. The project of the business processes reengineering at each enterprise is unique. But it is possible to point out the main questions which demand the permission:

- What basic needs do we want to satisfy and for whom?

- Why do we want to satisfy these requirements? Will they be coordinated with the general strategy of the enterprise, the reference points of development of the industry, economy, interests of the environment?

- Where is it necessary to satisfy these requirements?

- When is it necessary to satisfy these requirements?

- How will these requirements satisfied? Who will do that? Which technologies are necessary?

The task of reengineering for the Russian enterprises is to carry out high-quality improvement of the main business processes with simultaneous implementation of new information technologies for the purpose of modernization and significant increase in the efficiency, social and environmental responsibility of business.

\section{References}

1. Y. Malhotra, IEEE Engineering Management Review 26-3, 12-25 (1998)

2. M. Hammer, Harvard Business Review (Harvard, 1990)

3. M. Hammer, J. Champy, Reengineering the Corporation: A Manifesto for Business Revolution (Harper Business, 2001)

4. T.H. Tietenberg, Environmental economics and policy (HarperCollins College Publishers, New York, 1994) 
5. P. Bellagente, F. Bonafini, C. Crema, A. Depari, P. Ferrari, A. Flammini, G. Lenzi, M. Pasetti, S. Rinaldi, E. Sisinni, 2018 IEEE International Workshop on Metrology for Industry 4.0 \& IoT, (2018). DOI: 10.1109/METROI4.2018.8439039

6. E.G. Oykhman, E.V. Popov, Business reengineering (Finance and statistics, Moscow, 2011)

7. E.V. Popov, M.D. Shapot, Reengineering of business processes and intellectual modeling (Stroyizdat, Moscow, 2006)

8. M. Robson, T. Ullakh, Practical guidance on business processes reengineering (Audit, UNITY, Moscow, 2007)

9. I.V. Ivashkina, Matters of regional ecology 1, 26-31 (2010)

10. A.E. Gutnov, I.G. Lezhava, Future of the city (Stroyizdant, Moscow, 2007)

11. V. Blinov, Science and life 3, 30 (2009)

12. A.V. Gorodkov, Higher education institutions news. Construction 5, 98 (2000) 